\title{
PENGARUH KUALITAS PELAYANAN TERHADAP KEPUASAN PASIEN RAWAT INAP UNIT GEDUNG A-RSCM JAKARTA
}

\author{
Indra Jaya \\ Dosen Tetap Fakultas Ekonomi Universitas Pakuan \\ Lecturer of Economic Faculty at Pakuan University \\ Indra Syarufudin \\ Mahasiswa Fakultas Ekonomi Universitas Pakuan \\ Student of Economic Faculty at Pakuan University
}

\begin{abstract}
ABSTRAK
Rumah sakit adalah suatu institusi yang bergerak dibidang pelayanan kesehatan, namun saat ini banyak mengalami perubahan. Pada awal perkembangannya, rumah sakit adalah lembaga yang berfungsi social, tetapi dengan adanya rumah sakit swasta, menjadikan rumah sakit lebih mengacu sebagai suatu industry yang bergerak dalam bidang pelayanan kesehatan dengan melakukan pengelolaan yang berdasar pada manajemen badan usaha. Hasil yang didapat dari penelitian ini adalah secara umum tingkat kepuasan di RSUPN Dr. Cipto Mangunkusumo Jakarta cukup baik. Penulis menjelaskan melalui tingkat kesesuaian antara kinerja dan harapan menurut persepsi responden sebesar 100,03\%. Adapun analisis hubungan ChiKuadrat menyimpulkan bahwa kualitas pelayanan RSUPN dDr. Cipto Mangunkusumo Jakarta khususnya ruang rawat inap kelas 2 unit gedung A, memeberikan pengaruh signifikan terhadap kepuasan pelnggannya, baik pada tingkat kinerja maupun pada tingkat harapan. Pada tingkat kinerja, di peroleh statistic Chi-Kuadrat sebesar 383,938 yang signifikan pada taraf keyakinan 95\%. Sedangkan pada tingkat harapan, diperoleh statistic Chi-Kuadrat sebesar 312,468 yang signifikan pada taraf keyakinan $95 \%$.
\end{abstract}

Kata kunci : kualitas pelayanan dan kepuasan pelayanan.

\begin{abstract}
The hospital is an institution in the field of health care, but this time a lot of changes. At the beginning of its development, the hospital is an institution that serves the social, but with the private hospitals, making the hospital more refers as an industry engaged in the field of health care by management based on the management of a business entity. The results obtained from this study is the general level of satisfaction in RSUPN Dr. Cipto Mangunkusumo good enough. The author explains through the level of concordance between performance and expectations according to respondents' perception of 100.03\%. As for the relationship Chi-Square analysis concluded that the quality of service RSUPN DDR. Cipto Mangunkusumo especially inpatient class 2 in unit A building, give significant influence on satisfaction for the customer/patient, both at the level of performance and the level of expectation. At the level of performance, obtained statistical Chi-Square at 383.938 that was significant at $95 \%$ confidence level. While the level of expectation, obtained statistical Chi-Square at 312.468 that was significant at $95 \%$ confidence level.
\end{abstract}

Keywords: service quality and service satisfaction.

\section{Pendahuluan}

Rumah sakit adalah suatu institusi yang bergerak dibidang pelayanan kesehatan, namun saat ini banyak mengalami perubahan. Pada awal perkembangannya, rumah sakit adalah lembaga yang berfungsi sosial, tetapi dengan adanya rumah sakit swasta, menjadikan rumah sakit lebih mengacu sebagai suatu industri yang bergerak dalam bidang pelayanan kesehatan dengan melakukan pengelolaan yang berdasar pada manajemen badan usaha.

Rumah sakit memiliki peran yang sangat strategis dalam upaya mempercepat peningkatan derajat kesehatan masyarakat. Paradigma baru pelayanan kesehatan masyarakat, rumah sakit memberikan pelayanan berkualitas sesuai kebutuhan dan keinginan pasien 
dengan tetap mengacu pada kode etik profesi dan medis. Dalam perkembangan teknologi yang pesat dan persaingan yang semakin ketat, maka rumah sakit dituntut untuk melakuakan peningkatan kualitas pelayananan.

Menurut Khotler dan Keller (2009, 143-144) "Kualitas adalah jaminan terbaik atas loyalitas pelanggan, pertahanan terkuat perusahaan dalam menghadapi persaingan dan satu-satunya jalan untuk mempertahankan pertumbuhan dan penghasilan."

Faktor manusia sebagai pemberi pelayanan terhadap publik dalam organisasi dianggap sangat menentukan dalam menghasilkan pelayanan yang berkualitas. Sumber daya manusia yang ada baik medis maupun non medis yang bertugas dirumah sakit harus memahami cara melayani konsumennya dengan baik, baik itu kepada pasien dan keluarga pasien, karena mereka adalah konsumen utama dirumah sakit.

Adapun tujuan dari penlitian ini adalah: 1) Untuk mengetahui pelayanan yang diterapkan kepada pasien Rawat Inap kelas 2 di unit Gedung A-RSCM; 2) Untuk mengetahui tingkat kepuasan konsumen; dan 3) Untuk mengetahui pengaruh pelayanan terhadap kepuasan pasien Rawat Inap kelas 2 di Unit gedung A-RSCM.

\section{Metode penelitian}

Desain penelitian yang digunakan yang digunakan dalam penelitian ini adalah metode kuantitatif dengan metode penelitian yang bersifat asosiatif kausal yaitu untuk mengetahui apakah ada hubungan antara kualitas pelayanan terhadap kepuasan pasien. Serta metode verifikatif digunakan untuk pengujian hipotesis. Adapun prosedur pengumpulan data yang digunakan pada penelitian ini adalah metode survei, dimana teknik pengumpulan data yang penulis lakukan dalam melaksanakan penelitian ini, yaitu observasi secara langsung dalam lingkungan ruang Rawat Inap Unit Gedung A-RSCM dan kuisioner yang dibagikan kepada pasien ataupun keluarga pasien.

\section{Hasil dan Pembahasan}

3.1. Pelaksanaan kualitas pelayanan unit Rawat Inap Gedung ARSCM Jakarta

Di dalam suatu perusahan jasa, pelayanan merupakan kunci dari kesuksesan. Kualitas pelayanan adalah tingkat dimana pelayanan yang diberikan bisa sesuai dengan kepuasan pelanggan atau tingkat dimana personil jasa benarbenar memahami apa yang diharapkan oleh pelanggan serta bisa memahami kepuasan dan keinginan pelanggan.

Adapun jenis-jenis pelayanan yang diberikan oleh Rumah Sakit Umum Pusat Nasional Dr. Cipto Mangunkusumo Jakarta yaitu rawat inap dan rawat jalan. Untuk mengetahui sejauh mana pelayanan yang telah diberikan oleh RSCM Jakarta sebagai upaya untuk mencapai kepuasan dapat dilihat melalui beberapa kriteria, diantaranya:

1. Kehandalan (reliabilitas)

Rumah sakit Dr. Cipto Mangunkusumo berusaha untuk menampilkan pelayanan yang dijanjikan secara akurat. Untuk memenuhi hal tersebut RSCM Jakarta berusaha memberikan kemudahan pasien dalam mendapatkan pelayanan. Selain itu RSCM Jakarta telah mempermudah pendaftaran kamar rawat inap.

2. Daya Tanggap (responsiveness) Rumah sakit Dr. Cipto Mangunkusumo selalu berusaha membantu konsumen dan memberikan pelayanan yang cepat 
dan tepat sesuai dengan yang diinginkan konsumen.

3. Jaminan (assurance)

Rumah sakit Dr. Cipto Mangunkusumo sangat memperhatikan sikap perawat terhadap pasien, karena RSCM Jakarta menganggap bahwa pelanggan adalah raja, maka perawat harus bersikap menyenangkan dalam menghadapi pasien. Perawat diberikan masukan-masukan untuk menghadapi pasien dan dianjurkan untuk selalu bersikap ramah tamah dan selalu sopan, serta berpenampilan rapid an menarik.

\section{Empati (empathy)}

Sebagai perusahaan jasa Rumah sakit Dr. Cipto Mangunkusumo Jakarta sangat mengutamakan kualitas pelayanan yang diberikan kepada konsumen. Namun apa yang telah diberikan RSCM Jakarta masih belum sempurna untuk memberikan pelayanan yang terbaik kepada konsumen, para dokter, perawat, staf administrasi harus selalu bersikap peka menghadapi konsumen. Para dokter, perawat, staf administrasi selalu didorong cepat tanggap dalam melayani konsumen, selain untuk kepuasan konsumen hal tersebut juga dimaksudkan agar pekerjaan tidak menumpuk.

\section{Berwujud (tangible)}

Fasilitas yang lengkap dan peralatan yang modern merupakan salah satu faktor pendorong pekerjaan, hal tersebut disadari sepenuhnya oleh Rumah Sakit Dr. Cipto Mangunkusumo Jakarta untuk dapat memberikan kenyamanan dan kepuasan kepada konsumen, kini RSCM Jakarta sedang memperluas bangunan dan memperbaiki serta mengganti peralatan yang sudah tidak layak pakai.

\subsection{Kepuasan pasien Rawat Inap Gedung A-RSCM Jakarta}

Secara umum tingkat kesesuaian tingkat harapan dan tingkat kinerja terhadap kualitas pelayanan RSUPN Dr. Cipto Mangunkusumo mencapai $100,03 \%$. Karena mencapai diatas $100 \%$, disimpulkan secara umum kualitas pelayanan yang dilaksanakan RSUPN Dr. Cipto Mangunkusumo telah memenuhi kepuasan konsumen.

\subsection{Pengaruh kualitas pelayanan terhadap kepuasan pasien RSUPN Dr. Cipto Mangunkusumo Jakarta}

1. Evaluasi tingkat kinerja terhadap indicator kulitas pelayanan.

Dengan menggunakan taraf nyata $\alpha=0,05$ dan derajat bebas $\mathrm{Df}=68$ diperoleh nilai kritis $\mathrm{X}_{\text {tabel }}^{2}$ sebesar 88,25. Sedangkan besarna nilai $X^{2}$ hitung sebesar 383,938 karena $\mathrm{X}^{2}$ hitung $383,938>\mathrm{X}_{\text {tabel }}^{2}$ 88,25 maka Ho ditolak, artinya dengn tingkat kepercayaan sebesar 95\% kualitas pelayanan jika dilihat pada tingkat kinerja memberikan pengaruh signifikan terhadap kepuasan pasien di RSUPN Dr. Cipto Mangunkusumo, khususnya untuk pasien ruang rawat inap kelas 2 gedung A.

Sedangkan nilai koefisien kontingensi $\mathrm{C}$ sebesar 0,419 termasuk dalam tingkat hubungan yang lemah.

2. Evaluasi tingkat harapan terhadap indikator kualitas pelayanan. 
Dengan menggunakan taraf nyata $\alpha=0,05$ dan derajat bebas $\mathrm{Df}=68$ diperoleh nilai kritis $\mathrm{X}_{\text {tabel }}^{2}$ sebesar 88,25 . Sedangkan besarna nilai $X^{2}{ }_{\text {hitung }}$ sebesar 312,468 . Karena $\mathrm{X}^{2}{ }_{\text {hitung }} 312,468>\mathrm{X}_{\text {tabel }}{ }$ 88,25 maka Ho ditolak, artinya dengn tingkat kepercayaan sebesar 95\% kualitas pelayanan jika dilihat pada tingkat kepuasan memberikan pengaruh signifikan terhadap kepuasan pasien di RSUPN Dr. Cipto Mangunkusumo, khususnya untuk pasien ruang rawat inap kelas 2 gedung A.

Sedangkan nilai koefisien kontingensi $\mathrm{C}$ sebesar 0,385 termasuk dalam tingkat hubungan yang lemah.

\section{Kesimpulan}

1. Secara umum tingkat kepuasan di RSUPN Dr. Cipto Mangunkusumo Jakarta dijelaskan melalui tingkat kesesuaian antara kinerja dan harapan menurut persepsi responden sebesar 100,03\%. Beberapa indikator kualitas pelayanan yang dilaksanakan dengan baik menurut persepsi responden yakni kemudahan memberikan pelayanan $(102,21 \%)$, pemberian pelayanan yang nyaman (101.43\%), kemauan memberikan pelayanan yang khusus kepada pasien $(112,26 \%)$, bersikap sopan dalam memberikan pelayanan (126,35\%), bersikap ramah terhadap pasien $(101,13 \%)$, kepekaan dalam menanggapi keluhan pasien $(104,86 \%)$, sikap terhadap pasien dalam melakuakan tugas (105,9\%), cepat tanggap dalam melayani pasien $\quad(115,38 \%) \quad$ tidak memandang status sosial
(102,55\%) dan lingkungna dalam yang terjaga dengan baik $(102,82 \%)$. Sedangkan indicator kualitas pelayanan yang dipersepsikan belum baik oleh responden dan perlu ditingkatkan yakni kemudahan pendaftaran pasien baru (90,88\%), kemudahan proses pembayaran $(95,32 \%)$, kemudahan dalam mendapatkan ruangan $(95,68 \%)$, pemberian pelayanan secara cepat $(63,73 \%)$, berpenampilan rapih dn menarik (97,98\%), lingkungn luar yang belum terjaga dengan baik $(99,02 \%)$ dan pnunjang fasilitas peralatan medis $(100 \%)$

2. Analisis hubungan Chi-Kuadrat menyimpulkan bahwa kualitas pelayanan RSUPN Dr. Cipto Mangunkusumo Jakarta khususnya ruang rawat inap kelas 2 gedung $\mathrm{A}$, memberikan pengaruh signifikan terhadap kepuasan pelaggannya, baik pada tingakta kinerja maupun tingkat harapan. Pada tingkat kinerja, diperoleh nilai Chi-Kuadrat sebesar 383,938 yang signifikan pada taraf keyakinan $95 \%$. Sedangka pada tingkat harapan, diperoleh statistic Chi-Square sebesar 32,468 yang signifikan pada taraf keyakinan $95 \%$

\section{Daftar Pustaka}

Adrian Payne. 2002. Service Marketing Pemasaran Jasa. Andi. Yogyakarta.

Ahmad Subagyo. 2010. Marketing Bussines. Mitra Wacana Medika. Jakarta.

Boyd, Harper W, Dkk. 2000. Manajemen Pemasaran. Edisi Prtama. Erlangga. Bandung. 
Buchari Alma. 2004. Manajemen Pemasaran Dan Pemasaran Jasa. Alfabeta. Bandung.

Fajar Laksana. 2008. Manajemen Pendekatan Praktis. Graha Ilmu. Yogyakarta.

Fandy Tjipto. 2006. Manajemen Jasa. Edisi Keempat. Andi. Yogyakarta.

Fandy Tjipto, 2008. Strategi Pemasaran. Edisi Ketiga. Andi Yoyakarta.

Hartono. 2010. Manajemen Pemasaran Untuk Rumah Sakit. Jakarta. Rineka Cipta.

Kotler Philip Dan Gary Amstrong. 2004. Dasar-Dasar Pemasaran. Jilid 1. Prendhallindo. Jakarta.

Kotler Philip Dan Keller Kevin Lane. 2006. Marketing Manajement. Twelfth Edition, By Person Education, Ic., Upper Saddle River, New Jersey.

Kotler Philip Dan Gary Amstrong. 2010. Principle of Marketing. $13^{\text {th }}$ Edition. Pearson Prentice Hall.

Kotler Philip Dan Gary Amstrong. 2012. Principle of Marketing. $14^{\text {th }}$ Edition. Pearson Prentice Hall.

Kotler Philip And Kevin L. Keller. 2009, Manajemn Pemasaran. Edisi 13, Jakarta: Erlangga.

Lovelock,C. H. Dan Wright, L. K. 2007. Manajemen Pemasaran Jasa. Jakarta. Indeks

Lupiyoadi Dan Hamdani. 2008. Manajemen Pemasaran Jasa. Esisi 2. Jakarta: Salemba Empat.

M. Manurung. 2002. Manajemen Pemasaran. Gramedia Bandung.

Mursid. 2005. Manajemen Pemasaran. Gramedia Bandung. 